\title{
Pelatihan Pemanfaatan Smartphone Android Sebagai Media Pembelajaran Bagi Orang Tua Kelurahan Sidokerto Kecamatan Bumi Ratu Nuban
}

\author{
Erni Mariana ${ }^{1}$; Novita $^{2}$; Kusuma Wardany ${ }^{3 *}$; Reni Permata Sari ${ }^{4}$ \\ Published online: 5 July 2021
}

\begin{abstract}
This community service program has the following objectives, namely, 1) To introduce the use of an Android Smartphone with the Android application in the process of teaching and learning activities in class for parents/guardians of Sidokerto Village, Bumi Ratu Nuban District, Bumi Ratu Nuban District, 2) To increase the use of Android smartphones with the Android application for Parents/guardians of Sidokerto Urban Village, Bumi Ratu Nuban District. The results of this dedication show that there is high enthusiasm from the participants during the delivery of the material and practices that are carried out. Apart from being active in providing responses and asking the participants, it also shows that the presentation given has been directly practised in the process of teaching and learning activities that they carry out. In this case, the participants feel they have had new experiences in the teaching and learning process, so the hope is that it can foster enthusiasm for learning and student creativity so that it can improve student achievement.
\end{abstract}

Keyword: Community Service, Learning Media, Android Smartphone

\begin{abstract}
Abstrak. Program pengabdian pada masyarakat ini memiliki tujuan yaitu, 1) Untuk mengenalkan pemanfaatan Smartphone android dengan aplikasi andorid dalam proses kegiatan belajar mengajar di kelas pada Orang Tua/Wali Murid Kelurahan Sidokerto Kecamatan Bumi Ratu Nuban, 2) Untuk peningkatan penggunaan pemanfaatan Smartphone android dengan aplikasi andorid bagi Orang Tua/Wali Murid Kelurahan Sidokerto Kecamatan Bumi Ratu Nuban. Hasil dari pengabdian ini menunjukkan bahwa adanya antusias yang tinggi dari peserta, selama penyampaian materi dan praktik yang dilakukan. Selain aktif memberikan tanggapan dan bertanya para peserta juga menunjukkan bahwa pemaparan yang disampaikan sudah dipraktikkan secara langsung dalam proses kegiatan belajar-mengajar yang mereka lakukan. Dalam hal ini peserta merasa mendapat pengalaman baru dalam proses belajar-mengajar, maka harapannya dapat menumbuhkan semangat belajar dan kreativitas siswa sehingga dapat meningkatkan prestasi siswa.
\end{abstract}

Kata kunci: Pengabdian, Media Pembelajaran, Smartphone Android

\section{PENDAHULUAN}

Proses pendidikan pada hakikatnya merupakan proses interaksi 2 arah yang mengaitkan komunikasi antara guru dengan siswa. Proses komunikasi ini terdiri atas aktivitas penyampaian pesan (modul pendidikan) antara pengirim (guru) kepada penerima (siswa). Penyampaian pesan

\section{1,2,3,4 Universitas Nahdaltul Ulama Lampung \\ *) corresponding author}

Kusuma Wardany

Universitas Nahdaltul Ulama Lampung Jalan Raya Pantai Lintas Timur, Purbolinggo, Lampung Timur, Indonesia

Email: kusuma.wardany@ymail.com memerlukan pemakaian media yang pas supaya pendidikan bisa berjalan dengan efisien serta efektif. Oleh sebab itu, media pendidikan jadi lumayan berarti sebab tanpa media hingga komunikasi tidak hendak terjalin serta proses pendidikan tidak hendak berlangsung maksimal.

Penafsiran media pendidikan yang banyak dikemukakan oleh pakar, salah satunya dikemukakan oleh Rossi serta Breidle (dalam Wina Sanjaya, 2013: 
163) kalau media pendidikan merupakan segala perlengkapan serta bahan yang bisa dipakai buat menggapai tujuan pembelajaran semacam radio, tv, novel, koran, majalah, serta sebagainya.

Tetapi, bersamaan dengan pertumbuhan teknologi data serta komunikasi hingga guru bisa menggunakan internet selaku media pendidikan serta penunjang proses pendidikan yang maksimal. Sehingga alasan- alasan yang dikemukakan diatas bisa dicarikan solusinya dengan pemanfaatan internet. Dengan layanan fitur yang bermacam- macam serta berbasis IT, guru serta siswa bisa mengaksesnya secara online serta ada banyak aplikasi yang menggratiskan pemakainya. Antara lain merupakan pemakaian web selaku media pendidikan.

Sekolah dengan seluruh sumber daya pendidikan yang terdapat pula bertugas buat membuat siswa supaya siap serta sanggup buat melanjutkan ke jenjang pembelajaran yang lebih besar. Oleh karena itu sekolah butuh mengupayakan supaya tenaga pendidik (guru) bisa mentransfer kemampuannya cocok dengan kompetensi supaya para siswa terampil serta sanggup bersaing ke jenjang pembelajaran yang lebih besar ataupun didunia kerja. Buat menunjang perihal itu hingga butuh media pendidikan yang menarik supaya siswa bisa belajar aktif serta bisa meresap pengetahuan yang diajarkan oleh gurunya baik di jam sekolah ataupun diluar jam sekolah.

Edi, Melly, Pratama (2017) menjelaskan bahwa Media pembelajaran secara umum berdasarkan teori yang telah dipaparkan adalah alat bantu dalam proses belajar dan mengajar. Segala sesuatu yang dapat dipergunakan untuk merangsang pikiran, perasaan, perhatian dan kemampuan atau keterampilan pembelajar melalui kegiatan komunikasi dan sehingga dapat mendorong terjadinya proses belajar dapat dikatakan sebagai media pembelajaran. Pada perkembangannya dalam kegiatan pedidikan media digunakan sebagai sumber belajar yang dapat memberikan pemahaman yang nyata bagi peserta didik, jenis media yang banyak digunakan dalam kegiatan pembelajaran adalah media dengan jenis multimedia.

Edi, Melly, Pratama (2017) menjelaskan bahwa Smartphone ialah perangkat seluler yang dilengkapi dengan sistem pembedahan seperti PC. Smartphone dapat mengimplementasikan berbagai wujud multimedia semacam halnya PC cuma saja keunggulannya merupakan smartphone memiliki mobilitas yang besar serta dapat dioperasikan secara lebih efisien. Smartphone merupakan perangkat telepon seluler yang dikembangkan dengan menerapkan sistem operasi berbasis komputer. Sistem operasi yang digunakan pada smartphone saat ini pada umumnya adalah sistem operasi android yang dikembangkan oleh Google ${ }^{\mathrm{TM}}$ dan iOS yang dicetuskan oleh perusahaan komputer Apple ${ }^{\mathrm{TM}}$. Perkembangan smartphone hingga saat ini tidak hanya sebatas sebagai alat komunikasi, namun saat ini smartphone banyak digunakan sebagai media pembelajaran. Mengingat penggunaan smartphone yang tinggi oleh siswa maka sudah seharusnya guru memfasilitasi siswa menggunakan smartphone. Sebagai media pendukung pembelajaran. Seperti yang dinyatakan oleh Minovic (2012:893) bahwa siswa saat ini telah tumbuh dengan menggunakan perangkat seperti komputer, ponsel, dan konsol video untuk hampir setiap kegiatan; dari kegiatan belajar, bekerja, atau hanya sebatas hiburan. Kitchenham (2011:9) berpendapat bahwa pemanfaatan smartphone dalam program pendidikan menjadikan perangkat ini sebagai salah satu bentuk perangkat yang dapat digunakan sebagai alternatif dalam pengembangan media. Penggunaan smartphone dalam pendidikan dikenal sebagai teknologi mobile learning (m-Learning). Pemanfaatan m-Learning dinyatakan oleh Gonzalez (2015:32) dapat memberikan kontribusi yang positif kepada peserta untuk mengakses bahan belajar ataupun sebagai media pembelajaran. Selain itu, Laurillard (2007) berpendapat bahwa dengan menggunakan smartphone dalam pendidikan, membuat teknologi ini memiliki peran yang sentral untuk dapat digunakan sebagai sarana penyampai informasi kepada siswa melalui teknologi perangkat mobile.

Pemanfaatan smartphone sebagai media pembelajaran didukung oleh Rogozin (2012:913) yang menyatakan bahwa dengan menggunakan smartphone sebagai media pembelajaran memberikan kesempatan belajar yang lebih mendalam bagi siswa karena dengan menggunakan smartphone siswa dapat mengembangkan pembelajaran melalui penelusuran informasi dari internet, serta melatih keterampilan mereka dalam melaksanakan praktikum karena prinsip mobilitas yang dimiliki 
oleh smartphone. Lebih lanjut dikatakan bahwa dengan menggunakan smartphone siswa mampu membangun kompetensi mereka dengan cara yang dinamis.

Ependi, U., \& Sopiah, N. (2015) menjelaskan bahwa Teknologi dikala ini telah sangat berkembangan sangat pesat, paling utama teknologi mobile. Pemakaian Handphone (HP) bukan ialah kebutuhan sekunder lagi, hendak tetapi ialah kebutuhan primer yang harus dipunyai oleh orang. Tidak cuma orang berusia serta anak muda yang memakai HP, namun pula kanak- kanak telah dapat memakainya. Kedudukan orang tua sangatdiperlukan buat mengestimasi penggunaan HP supaya tidak digunakan secara kelewatan, mengingat perlengkapan ini telah dapat informasi apa saja yang kita mau, jika terkoneksi dengan sarana internet. Kebanyakan siswa memakai HP ber-Android memakainya buat bermain "permainan atau game".

Pengguna Android mengunduh lebih dari 1,5 miliar aplikasi dan game dari Google Play setiap bulan. Bagi pengembang aplikasi, Android sangat dimungkinkan untuk mendistribusikan aplikasi yang sudah dibuat. Pengembang bisa menyebarkan aplikasinya secara luas untuk ratusan juta pengguna di berbagai perangkat ponsel, tablet dan lain-lain (Android Developer, 2014). Android merupakan salah satu sistem operasi yang bisa digunakan pada media nirkabel. Dalam hal ini media yang digunakan adalah Handphone.Berdasarkan hal tersebut, maka metode pengembangan perangkat lunak yang digunakan dalam penelitian ini adalah rekayasa perangkat lunak nirkabel (wireless software engineering). Ada beberapa kegiatan yang dilakukan dalam rekayasa perangkat lunak nirkabel ini, yaitu (Simarmata, 2010): perencanaan, analisis pengguna mobile, analisis skenario, desain arsitektur, implementasi, pengujian, penyebaran, evaluasi pelanggan, dan pemeliharaan.

Adaninggar, Lemmuela (2020) menjelaskan bahwa Pembelajaran daring menuangkannya dalam PowerPoint pun sangat sederhana dan mudah dipahami. Ketika menjawab pertanyaan dari peserta, pembicara juga langsung straight to the point [langsung pada pokok persoalan], memberi contoh yang mendukung jawaban mereka berdasarkan pengalaman." Namun demikian, kami juga mendapatkan beberapa umpan balik konstruktif tentang aspek yang masih dapat ditingkatkan, misalnya untuk memperbanyak materi tentang aplikasi PJJ rendah kuota internet dan implementasi teori dengan contoh-contoh konkret yang lebih banyak. Dari sini, kami menyadari keinginan yang besar dari para guru Bahasa Inggris, terutama guru-guru Bahasa Inggris SMA, untuk dapat menfasilitasi PJJ para siswa selama pandemi ini dengan seoptimal mungkin meskipun dengan segala keterbatasan yang ada. Semangat ini patut diapresiasi dan terus didukung. Di sinilah dosen Bahasa Inggris dapat mengambil peran untuk membantu para guru, memberikan pemahaman, informasi baru, dan bahkan memupuk semangat mereka bahwa selalu ada jalan dalam setiap kesulitan dan bahwa pandemi ini dapat dijadikan momentum untuk semakin mengasah kemampuan para guru baik secara pedagogik maupun profesional. Terlebih selama masa pandemi ini, para dosen, dengan keilmuan yang mereka miliki, berperan dalam mengenalkan dan memberikan pemahaman terhadap ilmu dan informasi baru serta mengembangkan kinerja dan profesionalitas guru berkelanjutan. Bentuk kontribusi tersebut, selain merupakan salah satu bagian dari Tridharma Perguruan Tinggi, secara langsung juga merupakan bentuk manifestasi dari nilai-nilai dasar Kedutawacanaan yang kami anut.

Indah, Susi, Rizki (2019) menjelaskan bahwa pembelajaran dengan menjelaskan materi kegiatan seperti pentingnya sebuah media pembelajaran berbasis tekhnologi di era milenial saat ini. Setelah itu, salah satu anggota tim pengabdian masyarakat menjelaskan tentang media pembelajaran scrabble online dan aplikasinya dalam pembelajaran Bahasa Inggris di kelas. guru - guru bahasa Inggris di sekolah mitra menyatakan bahwa games ini bersifat baru bagi mereka meskipun sebenarnya games ini sudah di kenal sebelum menjadi online yaitu berupa permainan menyusun kata di atas kertas atau di atas papan. Demikian kegiatan ini dapat menambah pengetahuan guru - guru Bahasa Inggris di sekolah mitra bertambah khususnya tentang scrabbale games online berbasis android.

Setelah melihat dan menganalisis kondisi tersebut, maka tim pengabdian masyarakat melakukan pengabdian kepada masyarakat dengan dengan topik Pelatihan Pemanfaatan Smartphone Android Sebagai Media Pembelajaran Bagi Orang Tua/Wali Murid Kelurahan Sidokerto Kecamatan Bumi Ratu Nuban dengan menggunakan bantuan Smartphone Android sebagai media pembelajaran dapat 
memudahkan para guru-guru dalam proses pembelajaran dan memantau perkembangan pembelajaran anak didiknya melalui pendampingan dari orang tua atau wali murid sebagai guru didalam lingkungan rumah.

\section{METODE PELAKSANAAN}

Pelaksanaan kegiatan pengabdian dilakukan dengan melalui rangkaian pelatihan yang dilakukan secara berkala dalam jangka waktu 3 Minggu pelaksanaan pengabdian. Secara sistematis pelatihan dilakukan sesuai dengan urutan, sehingga pelaksanan pengabdian dapat mencapai target utama yaitu meningkatkan kememapuan orang tua atau wali murid sebagai pendamping siswa yang dapat memanfaatkan teknologi smartphone dalam pendidikan. Melalui kegiatan pengabdian ini tentunya peran mitra dalam kegiatan menjadi objek utama dari pelaksanaannya. Mitra yang dalam hal ini adalah kelompok Orang Tua/Wali Murid Kelurahan Sidokerto Kecamatan Bumi Ratu Nuban. Kelompok Orang Tua/Wali Murid Kelurahan Sidokerto Kecamatan Bumi Ratu Nuban dalam hal ini merupakan mitra tunggal yang pada pelaksanaan akan di stimulus agar dapat mengikuti kegiatan secara aktif dan terampil. Akhir dari pelaksanaan pengabdian adalah mengukur dan menilai capaian dan tingkat keterlaksanaan kegiatan yang telah dilakukan. Muara dari pengabdian ini adalah peningkatan kompetensi orang tua/wali murid, oleh karena itu pengukuran keberhasilan dari kegiatan pengabdian ini adalah ketika orang tua atau wali murid telah mampu mendampingi siswa dalam menggunakan media pembelajaran yang dapat diimplementasikan pada penggunaan smartphone. Pelatihan diselenggarakan dengan ceramah, tanya jawab, dan praktik.

1. Ceramah dan Tanya Jawab

Metode ini bertujuan untuk menyampaikan rangkaian teori tentang pengertian dan perkembangan media pembelajaran.

2. Praktik

Pada sesi ini, peserta pelatihan akan dibimbing dalam menyiapkan Smartphone Android dalam mendampingi siswa mengikuti pembelajaran daring dirumah.

Adapun waktu pelaksanaan adalah hari Rabu, tanggal 21 Februari 2021, pukul 09.00 sampai dengan selesai. Lokasi pengabdian kepada masyarakat berlokasi di Kelurahan Sidokerto Kecamatan Bumi Ratu Nuban. Sasarannya adalah Orang Tua/Wali Murid Kelurahan Sidokerto Kecamatan Bumi Ratu Nuban yang berjumlah 15 orang.

\section{HASIL DAN PEMBAHASAN}

Kegiatan pengabdian kepada masyarakat ini telah dilaksanakan sesuai dengan jadwal yang telah ditentukan, di Kelurahan Sidokerto Kecamatan Bumi Ratu Nuban dengan objek sasaran yaitu orang tua/wali murid. Kegiatan dilakukan dengan menerapkan sistem ceramah dan tanyak jawab, sampai dengan kegiatan praktik. Pelatihan ini dilaksanakan dengan rangkaian secara berkala dalam jangka waktu 3 Minggu, berikut ini merupakan kegiatan yang dilakukan selama pelatihan:

a. Pertemuan Minggu Pertama

Pada pertemuan pertama terfokus pada penyampaian teori, yaitu dengan memberikan penjelasan tentang pentingnya pemanfaatan Smartphone android sebagai media pembelajaran bagi orang tua/wali murid. Pemberian materi dilakukan dengan cara langsung menggunakan proyektor. Setelah penyampaian materi pada pertemuan ini para peserta yang hadir diberikan 
kesempatan untuk bertanya sehingga pemateri dapat memberikan solusi dengan penggunaan alat bantu yang memanfaatkan teknologi.

\section{b. Pertemuan Minggu Kedua}

Pada pertemuan kedua pelaksanaan pengabdian ini terfokus pada praktik terkait dengan pemanfaatan aplikasi yang berbasis android. Selama proses pelaksanaan praktik dari peserta yang hadir menunjukkan adanya antusias yang besar, hal ini terlihat dari keaktifan peserta selama proses praktik serta banyaknya pertanyaan yang diajukan dari para peserta yang hadir.

c. Pertemuan Minggu Ketiga

Pada pertemuan ketiga, pemateri melakukan pengecekan apakah setelah praktik terkait dengan pemanfaatan aplikasi yang berbasis android ini digunakan dalam kegiatan mendampingi pembelajaran melalui online dan tatap muka. Hal ini dilakukan untuk mengetahui, sejauh mana para peserta mengaplikasikan atau mempraktikan secara langsung di kegiatan belajar-mengajar. Sehingga pemateri dapat mengetahui apakah ada kendala yang dialami selama proses kegiatan belajar-mengajar dengan menggunakan aplikasi yang berbasis android.

Setelah dilakukan pengecekan kepada seluruh peserta yang hadir, para peserta dalam proses belajar-mengajar sudah menggunakan atau memanfaatkan aplikasi byang berbasis android secara langsung sesuai dengan materi dan praktik yang sudah dilakukan di minggu sebelumnya. Hal ini menunjukkan bahwa para peserta sudah paham dengan materi yang disampaikan oleh para tim pemateri.

\section{KESIMPULAN DAN SARAN}

Berdasarkan uraian pelaksanaan kegiatan pengabdian ini, maka dapat ditarik kesimpulan sebagai berikut.

1. Kegiatan pengabdian ini dapat dikategorikan berhasil dari segi partisipasi peserta mengingat dari 25 calon target peserta yang diundang yang hadir sebanyak 26-29 orang.

2. Para peserta merasa kegiatan pengabdian ini sangat bermanfaat bagi mereka, karena sebagai oramg tua mereka merasa perlu untuk mempelajari Pemanfaatan dari Smartphone Android sebagai media penyampai pesan pembelajaran. Media ini dapat membantu pendidik dan orang tua dalam memandu atau mendampingi pembelajaran melalui online dan tatap muka (konvensional) sehingga dapat saling melengkapi. Hal tersebut juga memberikan pengalaman belajar baru bagi siswa sehingga proses belajar mengajar dapat lebih bervariatif dan inovatif.

3. Respon peserta atas kegiatan pengabdian yang dilaksanakan menyatakan bahwa, dari kualitas pemateri sangat baik. Peserta juga menyatakan sangat paham atas penjelasan yang telah diberikan oleh tim pengabdi.

4. Para peserta merasa dengan pengalaman baru dalam proses belajar-mengajar, maka diharapkan dapat menumbuhkan semangat belajar dan kreativitas siswa sehingga dapat meningkatkan prestasi siswa.

5. Para peserta mendapatkan ketrampilan dalam menyiapkan proses pembelajaran menggunakan media Smartphone android.

\section{Conflict of Interests}

The authors declared that no potential conflicts of interests with respect to the authorship and publication of this article. 


\section{DAFTAR PUSTAKA}

Ependi, U., \& Sopiah, N. (2015). Pemanfaatan Teknologi Berbasis Android Sebagai Media Belajar Matematika Anak Sekolah Dasar. Matrik, 17(2), 109-122. Terdapat Pada http://eprints.binadarma.ac.id/2768/

Gonzalez, M.A., Martin, M.E., Liamas, C., et al. (2015). Teaching and learning physics with smartphones. Journal of Cases on Information Technology, 17, 31-50.

Ismanto, E., Novalia, M., \& Herlandy, P. B. (2017). Pemanfaatan smartphone android sebagai media pembelajaran bagi guru SMA Negeri 2 kota Pekanbaru. Jurnal Pengabdian UntukMu NegeRI, 1(1), 42-47. Terdapat pada ejurnal.umri.ac.id/index.php/PengabdianUMRI/article/download/33/14

Kitchenham, A. (2011). Models for interdisciplinary mobile learning: delivering information to students. Hersey PA: IGI Global.

Laurillard, D. (2007). edagogical forms for mobile learning in: Pachler, N. (ed). Mobile learning: towards a research agenda. London: WLE Centre, IoE.

Minovic, M. (2012). TRAILER project overview: Tagging, recognition and acknowledgment of informal learning experiences.

Muzdalifah, I., Handayani, S., \& Novendra, R. (2019). Sosialisasi Penggunaan Media Pembelajaran Scrabble Online Berbasis Android Untuk Guru-Guru Bahasa Inggris Sd IT Al Birru. Lembaga Penelitian dan Pengabdian Kepada Masyarakat, 3(1), 94-99. Terdapat pada https://journal.unilak.ac.id/index.php/dinamisia/article/view/2197

Rogozin. (2012). Physics Learning Instruments of XXI Century. Proceedings of The World Conference on Physics Education 2012.

Sanjaya, Wina. (2013). Penelitian Pendidikan, Jenis, Metode dan Prosedur. Jakarta: Kencana Prenada Media Group.

Simarmata, Janner. (2010). Rekayasa WEB. Andi. Yogyakarta.

Subekti, A. S., \& Kurniawati, L. A. (2020). Pelatihan Mendesain Pembelajaran Daring Menarik Selama Pandemi Covid-19 dengan Teknologi Pembelajaran Sederhana. Dinamisia: Jurnal Pengabdian Kepada Masyarakat, 4(4), 588-595. Terdapat pada https://journal.unilak.ac.id/index.php/dinamisia/article/view/4679 